\title{
Identifying Pathological Pneumoperitoneum After Laparoscopic Surgery
}

\section{Laparoskopik Cerrahi Sonrası Patolojik Pnömoperitoneumun Belirlenmesi}

\author{
(1) K G Mathew1, (1) Faris Alaswad1, () Saajan Ignatius Pius² \\ ${ }^{1}$ NMC Specialty Hospital, Dubai, United Arab Emirates \\ ${ }^{2}$ General Surgery NMC Specialty Hospital Alnahda, Dubai, United Arab Emirates
}

\section{\|III\|I\|I ABSTRACT}

Aim: The study aims to analyze the frequency and extent of pneumoperitoneum after laparoscopic surgery and to differentiate routine post laparoscopy pneumoperitoneum from pneumoperitoneum due to possible bowel perforation.

Method: Pneumoperitoneum after laparoscopic surgery persists for a variable number of days and can mask pathological pneumoperitoneum due to the complication of bowel perforation at laparoscopic surgery. This study aims to find a simple radiological solution to this issue, so that pathological bowel perforation can be detected at the earliest and corrective action taken.

Results: We had four cases of bowel perforation after laparoscopic surgery, and, the clinical signs were subtle and not clearly indicating any peritonitis. Radiological tests on post operative day lwere inconclusive, as free gas was attributed to persisting carbon dioxide pneumoperitoneum. Hence a relook laparoscopy was delayed for 48 hrs, when clinical signs were obvious. This scenario presented a challenge to distinguish persisting carbon dioxide pneumoperitoneum post laparoscopy from pathological pneumoperitoneum.

Conclusion: We decided to measure by X-ray chest the width of gas under diaphragm in the usual laparoscopic procedures, on the first post operative day and compare this with the width of gas under diaphragm in the four cases of iatrogenic bowel perforation post laparoscopic surgery. It was found that iatrogenic bowel perforation at laparoscopy is characterized by a wider gas under diaphragm, with the width at widest point ranging from 1.5 $\mathrm{cms}$ to $2.0 \mathrm{cms}$. Hence a simple xray chest could raise suspicion of a bowel perforation complication, and dictate further investigations like computed tomography scan or relook laparoscopy at the earliest post operative period.

Keywords: Pneumoperitoneum post laparoscopy surgery, bowel perforation at laparoscopy diagnosis, radiology for post laparoscopy complication

\section{||म||||||| ÖZ}

Amaç: Bu çalışma, laparoskopik cerrahi sonrası pnömoperitoneum sıklığını ve şiddetini analiz etmeyi ve olası bağırsak perforasyonuna bağlı pnömoperitoneumu rutin laparoskopi sonrası gelişen pnömoperitoneumdan ayırt etmeyi amaçlamaktadır.

Yöntem: Laparoskopik cerrahiden sonra pnömoperitoneum birkaç gün devam eder ve laparoskopik cerrahinin bağırsak perforasyonu komplikasyonuna bağlı patolojik pnömoperitoneumu maskeleyebilir. Bu çalışma, bu konuya basit bir radyolojik çözüm bulmayı, böylece patolojik bağırsak perforasyonunun en erken dönemde tespit edilerek düzeltici önlemler alınabilmesini amaçlamaktadır.

Bulgular: Laparoskopik cerrahiden sonra bağırsak perforasyonu gelişen 4 hastamız vardı. Tamamında klinik bulgular belirsizdi ve net olarak peritoniti düşündürmüyordu. Serbest gaz, devam eden karbondioksit pnömoperitoneuma atfedildiği için ameliyat sonrası 1. gündeki radyolojik testler sonuçsuz kaldı. Bu nedenle, klinik belirtiler bariz olana kadar, yeniden laparoskopi 48 saat ertelendi. Bu senaryo, laparoskopi sonrası devam eden karbon dioksit pnömoperitoneumu patolojik pnömoperitoneumdan ayırt etmek için zorluk oluşturmuştur.

Sonuç: Ameliyattan sonraki ilk günde, olağan laparoskopik prosedürlerde, diyafram altındaki hava miktarını gögüs grafisi ile ölçmeye ve bunu laparoskopik cerrahi sonrası iyatrojenik bağırsak perforasyonu gelişen 4 hastamızdaki diyafram altındaki hava miktarı ile karşılaştırmaya karar verdik. Laparoskopi sonrası iyatrojenik barsak perforasyonu diyafram altında daha geniş bir hava görünümü ile karakterizedir ve en geniş noktada genişliği 1,5-2 cm arasında değişmektedir. Bu nedenle, basit bir göğüs röntgeni, bağırsak perforasyonu komplikasyonunu düşündürebilir ve ameliyat sonrası en erken dönemde bilgisayarlı tomografi görüntülemesi veya yeniden laparoskopi gibi daha ileri araştırmaların gerekliliğine işaret edebilir.

Anahtar Kelimeler: Laparoskopi sonrası pnömoperitoneum, laparoskopiyi takiben gelişen bağırsak perforasyonunun tanısı, laparoskopi sonrası komplikasyon için radyolojik inceleme

Address for Correspondence/Yazışma Adresi: K G Mathew, MD,

NMC Specialty Hospital, Dubai, United Arab Emirates

E-mail: mathkg@gmail.com ORCID ID: orcid.org/0000-002-8799-4305

Received/Gelis Tarihi: 20.06.2020 Accepted/Kabul Tarihi: 14.07.2020

${ }^{\odot}$ Copyright 2021 by Turkish Society of Colon and Rectal Surgery

Turkish Journal of Colorectal Disease published by Galenos Publishing House. 


\section{Introduction}

Pneumoperitoneum is an essential component of laparoscopic procedures, with carbon dioxide $\left(\mathrm{CO}_{2}\right)$ as the preferred gas, mainly because it does not support combustion and is easily excreted via the lungs. $\mathrm{CO}_{2}$ is absorbed 32 times quicker than room air when used in double-contrast barium enemas. Studies have identified the frequency and duration of pneumoperitoneum, with $46 \%$ of the patients confirmed to have signs of post-laparoscopic pneumoperitoneum that resolves within 1 week in most cases. ${ }^{1}$ This study aimed to quantify the extent of post-laparoscopic pneumoperitoneum and identify which level of pneumoperitoneum is likely to be pathological considering the size of the pneumoperitoneum and level of C-reactive protein (CRP). To our knowledge, no such study has focused on this issue. This information will help identify early (postoperative day 1) and occasional pathological pneumoperitoneum caused by iatrogenic bowel perforation.

Iatrogenic bowel perforation after laparoscopic surgery has an incidence of $0.13 \%^{2}$ and is known for the paucity of clinical signs. Any patient who develops unexplained abdominal pain, fever or an elevated white cell count and/ or an increase in CRP levels after a laparoscopic procedure should undergo early contrast-enhanced computed tomography (CT), and there should be a low threshold for repeat laparoscopy or laparotomy. ${ }^{3} \mathrm{~A}$ high level of suspicion and free gas finding can help arrive at an early diagnosis. On postoperative day 1 , plain X-ray chest findings and clinical signs are key elements that dictate further investigations such as CT and helps in the decision to perform a relook laparoscopy.

\section{Materials and Methods}

This prospective study enrolled a total of 60 patients who underwent laparoscopic surgery from 1 February 2012 to 30 November 2012 in our hospital. Cases were randomly chosen from the procedures performed by four surgeons. In this study, procedures were limited to laparoscopic cholecystectomy, laparoscopic appendectomy and laparoscopic hernia by transabdominal preperitoneal technique (Table 1).

The study population was composed of 48 male and 12 female patients, and $58 \%$ of the patients were $20-40$ years old (Table 2). Patients aged $<20$ years and pregnant women were excluded from the study.

Laparoscopic surgery was performed by one of four specialist general surgeons in our institute. For all the selected cases, pneumoperitoneum was achieved by a $1-\mathrm{cm}$ periumbilical incision using an optical trocar or a blunt-tipped metallic trocar. The total number of ports varied from 3 to 4 ports.
None of the surgeons used Veress needle technique. After initial entry, $\mathrm{CO}_{2}$ was inflated to achieve a pressure of 10$12 \mathrm{mmHg}$. The duration and difficulty of surgery were not taken into consideration for this study. At the end of the surgery, $\mathrm{CO}_{2}$ was expelled through the ports by opening the cannulas. The telescope was removed at the last moment after checking other port sites after cannula removal. Once the telescope cannula is removed, the abdomen is normally flat. No intra-abdominal suction of gas or other special method was used to expel the gas.

On postoperative day 1 , the patient was sent to the radiology room for a standing chest X-ray on the postero-anterior view. Any free gas under the diaphragm on either side was noted. The size of the pneumoperitoneum was quantified by measuring the diameter of the gas shadow at the widest spot.

Gaseous areas under the diaphragm of four cases of iatrogenic laparoscopic perforation, which occurred between 2004 and 2012, were analysed.

\section{Results}

The study population was composed of 48 male and 12 female patients, who were mostly in their $20 \mathrm{~s}$ and $30 \mathrm{~s}$ (Tables 1 and 2).

Various types of laparoscopic procedures were performed (Table 3).

Of the 60 patients, 20 (33.33\%) had pneumoperitoneum on postoperative day 1 , and most patients had only trace or

Table 1. Control patients

$\begin{array}{ll}\text { Age (years) } & \text { Patients }(\mathrm{n}=60) \\ 20-30 & 15 \\ 31-40 & 20 \\ 41-50 & 17 \\ 51-60 & 6 \\ >60 & 2\end{array}$

Table 2. Sex distribution

$\begin{array}{ll}\text { Sex } & \text { Number of patients }(\mathrm{n}=60) \\ \text { Male } & 48 \\ \text { Female } & 12\end{array}$

Table 3. Laparoscopic procedures analysed

Laparoscopic appendectomy 20 cases

Laparoscopic cholecystectomy 21 cases

Laparoscopic hernia 19 cases 
mild amounts, with only one each in the moderate and large category. In 13 (21\%) patients, the pneumoperitoneum was unilateral under the right dome of the diaphragm, and in 7 cases $(11.67 \%)$, there was gas under both domes of the diaphragm (Table 4, 5).

During the period from January 2005 to December 2012, we identified four cases of post-laparoscopic bowel perforation. Cases with laparoscopic iatrogenic bowel perforation

Post-laparoscopic cholecystectomy

Post-laparoscopic varicocoelectomy

Post-laparoscopic hernia repair by TAPP technique

Post-laparoscopic appendectomy

Three laparoscopic procedures were performed by different surgeons in our hospital, and one case was referred to us from an external hospital. In all cases, X-ray of the abdomen and chest was carried out, but free gas was attributed to residual $\mathrm{CO}_{2}$ after laparoscopic surgery, and all cases had limited clinical signs on postoperative day 1 . Hence, a relook laparoscopy was performed only after $48 \mathrm{~h}$ in all four patients as there were more evident signs of peritonitis at that time and at CT (Table 6).

Table 4. Cases with gas under the diaphragm

Total number of cases: 60

Gas under diaphragm: 20 (33.33\%)

Unilateral gas: 13 (65.0\%)

Bilateral gas: 7 (35\%)

Table 5. Measurements of gas areas under the diaphragm

\section{Width of gas at the widest point number of cases}

$\begin{array}{lr}0.4 \text { to } 7 \mathrm{~mm} \text { (trace) } & 1 \\ 7.1 \text { to } 14 \mathrm{~mm} \text { (mild) } & 4 \\ 14.1 \text { to } 30 \mathrm{~mm} \text { (moderate) } & 1 \\ >30 \mathrm{~mm} \text { (large) } & 1\end{array}$

Table 6. Iatrogenic post-laparoscopic bowel perforations

\begin{tabular}{ll} 
Procedures first X-ray & $\begin{array}{l}\text { Width of gaseous area at the } \\
\text { widest point reop timing }\end{array}$ \\
\hline Laparoscopic cholecystectomy & $24 \mathrm{~h} 1.5 \mathrm{~cm} 48 \mathrm{~h}$ \\
Laparoscopic varicocoelectomy & $24 \mathrm{~h} 1.7 \mathrm{~cm} 72 \mathrm{~h}$ \\
Laparoscopic hernia repair & $24 \mathrm{~h} 2 \mathrm{~cm} 24 \mathrm{~h}$ \\
Laparoscopic appendectomy & $24 \mathrm{~h} 1.5 \mathrm{~cm} 48 \mathrm{~h}$
\end{tabular}

\section{Conclusion}

This study shows that despite the absence of special efforts to evacuate $\mathrm{CO}_{2}$ pneumoperitoneum after laparoscopic surgery, X-ray chest imaging on postoperative day 1 ( $24 \mathrm{~h}$ after surgery) shows free gas only in $33.33 \%$ of the cases, which is slightly below that reported in literature at $46 \%$. Moreover, in most cases, the amount of gas was small, with the vertical diameter of the gaseous area usually between 0.4 $\mathrm{mm}$ and $7 \mathrm{~mm}$.

Cases of iatrogenic perforations however were all characterised by the presence of free gas under the diaphragm with the widest diameter ranging from $1.5 \mathrm{~cm}$ to $2.0 \mathrm{~cm}$. Although it is not uncommon to see free gas under the diaphragm after laparoscopic surgery, a broad gas shadow is a cause for concern and dictates the need for CT and possible relook laparoscopy.

However, further studies are needed to analyse the implication of the width of the free gas under the diaphragm so that under appropriate clinical situations, prompt relook laparoscopy can be done to identify and rectify a possible iatrogenic bowel perforation.

Peer-review: Externally and internally peer reviewed.

\section{Authorship Contributions}

Concept: K.G.M., Design: K.G.M., Data Collection or Processing: K.G.M., F.A., S.I.P., Analysis or Interpretation: K.G.M., F.A., S.I.P., Literature Search: K.G.M., F.A., S.I.P., Writing: K.G.M., F.A., S.I.P.

Conflict of Interest: No conflict of interest was declared by the authors.

Financial Disclosure: The authors declared that this study received no financial support.

\section{References}

1. Millitz K, Moote DJ, Sparrow RK, Girotti MJ, Holliday RL, McLarty TD. Pneumoperitoneum after laparoscopic cholecystectomy: frequency and durationas seen on upright chest radiographs AJR Am J Roentgenol 1994:837-839.

2. Van der Voort M, Heijnsdijk EA, Gouman DJ. Bowel injury as a complication of laparoscopy: Br J Surg 2004:91:1253-1258.

3. Lament T, Watts F, Panerar S, MacFie J, Mattew D. Early detection of complications after laparoscopic surgery: summary of a safety report from the National Patient Safety Agency. BMJ 2011:342-c7221. 